\title{
Clinical Profile and Etiologies of Heart Failure at the Regional University Hospital Centre of Ouahigouya
}

\author{
Joël Bamouni1,2*, Salam Ouédraogo ${ }^{1,2}$, Edgar W. Ouédraogo ${ }^{1,2}$, Nongoba Sawadogo ${ }^{1,2}$, \\ Dangwé Temoua Naibe ${ }^{3,4}$, Dakaboué Germain Mandi' ${ }^{5}$, Hervé W. P. Kaboré5, Patrice Zabsonré ${ }^{5,6}$ \\ ${ }^{1}$ Department of Medicine, Ouahigouya Regional University Hospital, Ouahigouya, Burkina Faso \\ ${ }^{2}$ Higher School of Health Sciences, University of Ouahigouya, Ouahigouya, Burkina Faso \\ ${ }^{3}$ National General Reference Hospital of N’Djamena, N'Djaména, Chad \\ ${ }^{4}$ Université de N’Djamena, N’Djamena, N'Djamena, Chad \\ ${ }^{5}$ Cardiology Department, Yalgado Ouédraogo University Hospital, Ouagadougou, Burkina Faso \\ ${ }^{6}$ Health Sciences Training and Research Unit, Ouaga I University: Professor Joseph Ki-Zerbo, Ouagadougou, Burkina Faso \\ Email: ^bamounijoel@yahoo.fr
}

How to cite this paper: Bamouni, J., Ouédraogo, S., Ouédraogo, E.W., Sawadogo, N., Naibe, D.T., Mandi, D.G., Kaboré, H.W.P. and Zabsonré, P. (2019) Clinical Profile and Etiologies of Heart Failure at the Regional University Hospital Centre of Ouahigouya. Open Access Library Journal, 6: e5876.

https://doi.org/10.4236/oalib.1105876

Received: October 23, 2019

Accepted: November 12, 2019

Published: November 15, 2019

Copyright $\odot 2019$ by author(s) and Open Access Library Inc.

This work is licensed under the Creative Commons Attribution International License (CC BY 4.0).

http://creativecommons.org/licenses/by/4.0/

\section{(c) (i) Open Access}

\begin{abstract}
Introduction: Heart failure is a public health concern nowadays. It is the possible outcome of any cardiovascular pathology during its evolution. It is therefore one of the main causes of hospitalization but also of the death of these patients. Objective: The objective of our study was to describe the clinical profile and etiologies of acute heart failure at the Regional University Hospital Centre of Ouahigouya. Methods and Patients: This was a retrospective study over a twelve (12) months period from January 1 to December 31, 2017 in the medical department of the Regional University Hospital Centre of Ouahigouya. The patients admitted for heart failure during the period were our study population. Results: During our study period, we collected 123 cases of hospitalizations for heart failure, representing $8.33 \%$ of hospitalizations in the medical department. The average age of the patients was 52.7 \pm 21 years with a sex ratio of 0.80 . Dyspnea was the most observed functional sign $(97.56 \%)$ and heart failure was global in $88.62 \%$ of cases. Hypertensive heart disease was the most common etiology with $37.40 \%$. The average length of hospitalization was $10.18 \pm 2.64$ days. Conclusion: Our study showed that high blood pressure remains the main risk factor for heart failure in our context. This heart failure is willingly global and the average hospital stay remains relatively long.
\end{abstract}

\section{Subject Areas}

Cardiology 


\section{Keywords}

Heart Failure, Clinical Profile, Etiologies, Regional University Hospital

Center of Ouahigouya, Burkina Faso

\section{Introduction}

Heart failure is nowadays a major public health problem, the ultimate outcome of most cardiovascular diseases and one of the most frequent causes of hospitalization [1] [2]. His positive diagnosis is clinical (functional signs and clinical examination of diseases) [3], but suffers from a delay in our work context. Its treatment is now well codified and allows a reduction in morbidity and mortality so well conducted.

Because of the epidemiological transition, cardiovascular diseases are becoming more and more prevalent in developing countries, including ours. The prevalence of heart failure is increasing with aging and improved treatment in developed [4]. In our context, the increase in prevalence is mainly marked by delays in consultation and the chaotic care pathway of patients before the onset of heart failure [5]. This means that heart failure will increasingly become a daily occurrence in the health services of these countries.

Our hospital is located in the capital of one of the poorest regions in Burkina Faso (low purchasing power of the population). In addition, the University Hospital is very young (two years old). The objective of this first study on heart failure is to describe the clinical and etiological profile of this pathology in our practice in a semi-rural environment in Burkina Faso.

\section{Patients and Methods}

This was a descriptive retrospective study over a twelve (12) month period from January 1 to December 31, 2017. It took place in the medical department of the Ouahigouya Regional University Hospital.

Our sampling population included all patients hospitalized in medicine during the study period and the study population included patients admitted for heart failure.

Included in our study were patients with heart failure over 15 years of age who were hospitalized during the study period and whose clinical records were usable. All patients whose clinical records were not usable were excluded from the study.

Data collection was concerned about the socio-demographics, clinical, electrocardiogram, echocardiography and outcomes aspect during the period of hospitalization. The data were analyzed using Epi-info 3.5.3 and Rsoftware. Data confidentiality and patient anonymity were respected before the data were processed for ethical considerations. 


\section{Results}

During our study period, we collected 123 cases of hospitalizations for heart failure for 1476 hospitalizations, representing $8.3 \%$ of hospitalizations in the medical department.

\subsection{Socio-Demographic Characteristics}

The average age of the patients was $52.7 \pm 21$ years with extremes of 18 and 93 years. The male sex represented $44.7 \%(n=55)$ of patients or a sex ratio of 0.80 . Housewives and farmers accounted for $92.7 \%(n=114)$ of cases. Patients resided in urban areas in $29.3 \%(\mathrm{n}=36)$ of cases. Table 1 shows the distribution of patients by socio-demographics characteristics.

Table 1. Socio-demographic and clinical characteristics of patients at admission.

\begin{tabular}{|c|c|}
\hline Parameters & Value (\%) \\
\hline \multicolumn{2}{|l|}{ Age range (years) } \\
\hline$\leq 45$ & $51(41.4)$ \\
\hline $46-55$ & $10(8.1)$ \\
\hline $56-65$ & $19(15.5)$ \\
\hline$>65$ & $43(35)$ \\
\hline \multicolumn{2}{|l|}{ Sex } \\
\hline Male & $55(44.7)$ \\
\hline Female & $68(55.3)$ \\
\hline \multicolumn{2}{|l|}{ Profession, n (\%) } \\
\hline Housewife & $66(53.7)$ \\
\hline Cultivator & $48(39)$ \\
\hline Breeder & $2(1.6)$ \\
\hline Retired & $2(1.6)$ \\
\hline Student & $2(1.6)$ \\
\hline Employee & $3(2.4)$ \\
\hline \multicolumn{2}{|l|}{ Cardiovascular risk factors, $\mathrm{n}(\%)$} \\
\hline Hypertension & $46(37.4)$ \\
\hline Diabetes & $8(6.50)$ \\
\hline Dyslipidemia & $7(5.69)$ \\
\hline Smoking & $9(7.32)$ \\
\hline Alcohol abuse, n (\%) & $6(4.9)$ \\
\hline \multicolumn{2}{|l|}{ Functional and clinical signs at admission } \\
\hline NYHA Stage III-IV de la, n (\%) & $120(97.6)$ \\
\hline Cough, n (\%) & $45(36.6)$ \\
\hline Precordialgia, n (\%) & $71(57.7)$ \\
\hline Palpitations, n (\%) & $17(13.8)$ \\
\hline dizziness, n (\%) & $2(1.6)$ \\
\hline Lower limbs oedemas n (\%) & $64(52)$ \\
\hline Left heart failure syndrome, n (\%) & $6(4.9)$ \\
\hline Right heart failure syndrome, n (\%) & $6(4.9)$ \\
\hline Congestive heart failure syndrome, $\mathrm{n}(\%)$ & $109(88.6)$ \\
\hline
\end{tabular}

NYHA: New York Heart Association. 


\subsection{Clinical Characteristics at Admission}

We noted a history of hospitalization for heart failure in one case. High blood pressure was the cardiovascular risk factor in $37.4 \%(n=46)$ of cases. Table 1 shows the distribution of cardiovascular risk factors.

\subsection{Functional and Clinical Signs at Admission}

Ninety-seven decimal six percent $(\mathrm{n}=120)$ of patients had dyspnea. This dyspnea was assessed at a stage III or IV of the New York Heart Association (NYHA). Pre-cordialgia was noted in $57.7 \%(n=71)$ of patients. Patients had congestive heart failure in $88.9 \%(n=109)$ of cases. Table 1 presents the distribution of patients by functional and clinical signs at admission.

\subsection{Paraclinical Characteristics of Patients}

On electrocardiogram, complete arrhythmia by atrial fibrillation was noted in $13.1 \%(n=16)$ of cases and left ventricular hypertrophy in $75.6 \%(n=93)$ of cases. Severe alteration of left ventricular ejection fraction was noted in $78.1 \%(\mathrm{n}=$ 96). The average creatinine clearance was $152.9 \mu \mathrm{mol} / \mathrm{l}$. Table 2 shows the distribution of patients by paraclinical characteristics.

Table 2. Paraclinical characteristics.

\begin{tabular}{lc}
\hline \multicolumn{1}{c}{ Characteritics } & Value (\%) \\
\hline Electrocardiographic parameters & \\
Heart ratemean $\pm \mathrm{SD}$, cycles/minute & $114.4 \pm 15.1$ \\
Atrial fibrillation $\mathrm{n}(\%)$ & $16(13.1)$ \\
Ventricular extrasystoles $\mathrm{n}(\%)$ & $15(12.4)$ \\
Left ventricular hypertrophy $\mathrm{n}(\%)$ & $93(75.6)$ \\
Left atrial hypertrophy $\mathrm{n}(\%)$ & $58(47.2)$ \\
Myocardial ischemia $\mathrm{n}(\%)$ & $17(14.3)$ \\
Complete left branch block $\mathrm{n}(\%)$ & $2(1.6)$ \\
Complete right branch block $\mathrm{n}(\%)$ & $2(1.6)$ \\
Cardiac echographicparameters & $96(78.1)$ \\
Left ventricular ejection fraction $<40 \%, \mathrm{n}(\%)$ & $17(13.8)$ \\
Left ventricular ejection fraction between $40 \%-50 \%, \mathrm{n}(\%)$ & $10(8.1)$ \\
Left ventricular ejection fraction $\geq 50 \%, \mathrm{n}(\%)$ & $11.4 \pm 2.4$ \\
Biological parameters & \\
Fasting blood glucose, mean $\pm \mathrm{SD}, \mathrm{mmol} / 1$ & $5.3 \pm 1.8$ \\
Creatininemia, mean $\pm \mathrm{SD}, \mu \mathrm{mol} / \mathrm{l}$ & $152.9 \pm 270.8$ \\
Creatinine clearance, mean $\pm \mathrm{SD}, \mathrm{ml} / \mathrm{min} / 1.73 \mathrm{~m}{ }^{2}$ & $9(7.32)$ \\
Severe renal failure $\left(\mathrm{GFR}<30 \mathrm{ml} / \mathrm{min} / 1.73 \mathrm{~m}^{2}\right)$ & \\
hemoglobin level mean $\pm \mathrm{SD}, \mathrm{g} / \mathrm{dl}$ & \\
\hline
\end{tabular}

$\mathrm{SD}=$ standard deviation; GFR = glomerular filtration flow rate. 


\subsection{Etiologies of Heart Failure}

Heart failure was due in $37.4 \%(\mathrm{n}=46)$ of patients to hypertensive heart disease and valvulopathy in $14.6 \%(\mathrm{n}=16)$ of patients. Peripartum cardiomyopathy accounted for $13 \%(n=16)$ of heart failure cases and $19 \%$ of causes of heart failure in women. The distribution of patients by etiology is presented in Table 3.

\subsection{Evolution}

The average length of hospitalization was $10.2 \pm 2.6$ days with extremes of 4 and 15 days.

Treatment of patients was based on loop diuretics in $98.4 \%(\mathrm{n}=121)$, enzyme conversion inhibitors or angiotensin receptor antagonists in $93.5 \%(\mathrm{n}=115)$ and anti-aldosterone in $85.4 \%(\mathrm{n}=105)$ of cases. Beta-adrenergic blocking agents were used in $12.2 \%(\mathrm{n}=15)$ of patients. Table 4 shows distribution of patient according to receiving treatment.

Intra-hospital evolution is marked by death in $17.9 \%(n=22)$ of cases.

\section{Discussion}

The hospital prevalence of heart failure was $8.3 \%$ in our study, all medical causes combined. This prevalence is important if we take into account the share of heart failure in total cardiovascular disease. It is the terminal phase of the progression of most heart diseases; and this prevalence in our context could be explained by a delay in consultation-as evidenced by the main reason for consultation, which is NYHA Stage III-IV dyspnea-and a chaotic care path for patients. Indeed, Yameogo, in his study on the care pathways of patients with heart failure in Burkina Faso, showed that all actors (health workers, patients and the health system) each have a responsibility in the poor quality of patient care [5]. These delays could explain the significant alteration of the left ventricular ejection function (LVEF $<40 \%$ ) and the high mortality rate at $17 \%$. Yaméogo and Kologo in studies on the causes of cardiovascular mortality in

Table 3. Etiologies of heart failure.

\begin{tabular}{ccc}
\hline Etiologies & Frequency & Percentage \\
\hline Hypertensive heart disease & 46 & 37.4 \\
Ischemic heart disease & 8 & 6.5 \\
Idiopathic heart disease & 23 & 18.7 \\
Peri partum cardiomyopathy & 16 & 13 \\
Valvulopathy & 18 & 14.6 \\
Myopericarditis & 1 & 0.81 \\
Hypertrophic cardiomyopathy & 1 & 0.81 \\
Anemic heart & 3 & 2.43 \\
Chronic pulmonary heart & 7 & 5.69 \\
\hline
\end{tabular}


Table 4. Treatments received during hospitalization.

\begin{tabular}{ccc}
\hline Characteristic & Frequency & Percentage \\
\hline Loop diuretics & 121 & 98.4 \\
Nitrogen derivatives & 7 & 5.7 \\
Enzyme conversion inhibitors/Angiotensin receptor antagonists & 115 & 93.5 \\
Beta adrenergic blocking agents & 15 & 12.2 \\
Antialdosterones & 105 & 85.4 \\
Calcium antagonists & 2 & 1.6 \\
Anti platelets agents & 45 & 36.6 \\
Amiodarone & 4 & 3.2 \\
Digoxin & 3 & 2.4 \\
Enoxaparin & 2 & 1.6 \\
Antivitamin K & 2 & 1.6 \\
Statins & 4 & 3.2 \\
Insulin & 2 & 1.6 \\
Metformin & 5 & 4.06 \\
Blood transfusion & 5 & 4.06 \\
Iron & 4 & 3.25 \\
\hline
\end{tabular}

Ouagadougou and Koudougou respectively noted that cardiac IC was the leading immediate cause of death in our context [6] [7].

Hypertensive heart disease was the main etiology of heart failure in our study. This observation was made by Yameogo and Kologo in their study [6] [7]. This is due to delayed diagnosis of high blood pressure, poor compliance with treatment and patients' inability to provide regular treatment for high blood pressure [5] [8] [9]. A policy to prevent cardiovascular disease and the introduction of health insurance within society could improve not only primary and secondary prevention.

Our study was conducted in the medical department of the Ouahigouya Regional University Hospital. Ouahigouya is a medium-sized city in Burkina Faso, it is the capital of the northern region, which is one of the poorest in the country. This makes our patients among the poorest and makes it difficult for them to cope with health-related expenses, especially when it comes to chronic diseases such as heart failure. This situation partly explains the fact that the paraclinical check-up could not be done in all patients, particularly the etiological check-up, thus limiting our study, which was at their expense. This hospital has a limited technical platform in the exploration of this complex pathology and constitutes the crossroads of most pathologies in cardiology. Despite these limitations in our work, the results allow us to make an inventory and have a global vision of this pathology in our region.

\section{Conclusion}

Heart failure remains a frequent cause of admission of cardiac patients to the 
hospital. The main etiology, high blood pressure, can be prevented by primary prevention in the population and better medical care. Our study made it possible to make an inventory of this pathology which is serious with a poor prognosis. A better approach to the diagnosis and management of the causes of heart failure before hospitalization is needed and an improved technical platform is very important for reducing mortality in hospitals.

\section{Conflicts of Interest}

The authors declare no conflicts of interest regarding the publication of this paper.

\section{References}

[1] Miller, L.W. and Missov, E.D. (2001) Epidemiology of Heart Failure. Cardiology Clinics, 19, 547-555. https://doi.org/10.1016/S0733-8651(05)70242-3

[2] Roger, V.L. (2013) Epidemiology of Heart Failure. Circulation Research, 113, 646-659. https://doi.org/10.1161/CIRCRESAHA.113.300268

[3] Mosterd, A. and Hoes, A.W. (2007) Clinical Epidemiology of Heart Failure. Heart, 93, 1137-1146. https://doi.org/10.1136/hrt.2003.025270

[4] Savarese, G. and Lund, L.H. (2017) Global Public Health Burden of Heart Failure. Cardiac Failure Review, 3, 7-11.

[5] Yaméogo, R.A., Nikiéma, J.W.-Z., Bamouni, J., Naibe, D.T., Mandi, D.G., Kambire, Y., et al. (2018) Parcours de soins du patient insuffisant cardiaque au Burkina Faso. Revue Tunisienne de Cardiologie, 14, 175-183.

[6] Yameogo, A.R., Mandi, G., Millogo, G., Samadoulougou, A. and Zabsonre, P. (2014) Assessing Causes of Death in the Cardiology Department of Yalgado Ouédraogo University Hospital. The Pan African Medical Journal, 19, 155. https://doi.org/10.11604/pamj.2014.19.155.5286

[7] Kologo, K.J., Yaméogo, R.A., Bamouni, J., Balima, S., Millogo, G.R.C. and Zabsonré, P. (2016) Cardiovascular Death in the Regional Hospital of Koudougou. Open Access Library Journal, 3, 1-9. https://doi.org/10.4236/oalib.1103201

[8] Samadoulougou, A., Lengani, A., Yameogo, R., Millogo, G., Kologo, K., Toguyeni, B., et al. (2009) Hypertension artérielle maligne: Aspects épidémiologiques, cliniques et évolutifs dans le service de cardiologie du CHU Yalgado OUEDRAOGO. Annales de P Université de Ouagadougou, 7, 1-22.

[9] Yameogo, R.A., Mandi, D.G., Yameogo, N.V., Millogo, G.R.C., Kologo, K.J., Toguyeni, B.J.Y., et al. (2014) La super hypertension artérielle en milieu cardiologique au Burkina Faso. Annales de Cardiologie et d Angéiologie, 63, 151-154.

https://doi.org/10.1016/j.ancard.2014.04.010 